\title{
THE RELATIONSHIP BETWEEN SCHOOL DESEGREGATION AND ACADEMIC ACHIEVEMENT: A REVIEW OF THE RESEARCH
}

\author{
Meyer WeinberG*
}

[T]he outcome of any serious research can only be to make two questions grow where one question grew before.

- Thorstein Veblen

\section{INTRODUCTION}

Desegregation has become a major factor in American education. The courts have emphatically declared that segregation must end; school boards must take those measures "which promise realistically to convert promptly to a system without a 'white' school and a 'Negro' school, but just schools." 1 The Supreme Court soon made clear what "promptly" meant. ${ }^{2}$

[C] ] deliberate speed" for desegregation is no longer constitutionally permissible. ... [T] he obligation of every school district is to terminate dual school systems at once and to operate now and hereafter only unitary schools.

And the Supreme Court, in the Keyes case, indicated that these requirements were to extend to those school districts which had never operated "under a constitutional or statutory provision that mandated or permitted racial segregation in public education,"3 if there was evidence of purposeful segregation practiced by school officials in at least a portion of such districts.

Many have contended that Brown ${ }^{4}$ did not rest on social science evidence that segregation is psychologically harmful to Negro students, ${ }^{5}$ or on the belief

\footnotetext{
* Professor of History, Loop College, City Colleges of Chicago; Lecturer, Northwestern University School of Education; editor of Integrated Education.

1. Green v. County School Bd., 391 U.S. 430, 442 (1968).

2. Alexander v. Holmes County Bd. of Educ., 396 U.S. 19, 20 (1969) (emphasis added).

3. Keyes v. School Dist. No. 1, 413 U.S. 189, 191 (1973).

4. Brown v. Board of Educ., 347 U.S. 483 (1954).

5. There has been continuing debate over Brown's footnote eleven and whether the Supreme Court's opinion was based upon the sociological and psychological studies cited therein, whether this citation was merely "make-weight," or whether it was judicial fact-finding to which legal principles were then applied. See, e.g., C. Swisher, The Supreme Court in Modern Role 158 (1958); W. Workman, The Case for the South 26, 30, 197 (1960); Clark, The Social Scientists, the Brown Decision, and Contemporary Confusion, in Argument: The Oral Argument Before the Supreme Court in Brown v. Board of Education of Topeka, 1952-55 at xxxi, xxxvi (L. Friedman ed. 1969); Black, The Lawfulness of the Segregation Decisions, 69 YALE L.J. 421 (1960); Cahn, Jurisprudence, 30 N.Y.U.L. REV. 150 (1955).
} 
that the educational opportunity which the Court ordered states to provide equally without regard to race would lead to improved academic achievement on the part of Negro students. Nevertheless, since Brown, social scientists have sought to prove or disprove the linkage between racial and class integration and pupil performance. ${ }^{6}$

This article reviews school desegregation research that has been undertaken in this area, much of it unpublished. A major purpose, then, of this article is to disseminate information concerning these studies more extensively so that researchers and policy makers may build upon them. It is beyond the scope of this article, however, to systematically critique the methodology and approach used by the studies included herein. ${ }^{7}$ Having alerted the researcher to the existence of these studies and their general findings and conclusions, it must remain for each interested person to undertake the in-depth, critical analysis necessary to an understanding of the full implications of these studies and the likelihood that the results will be replicated elsewhere. While research on the impact of desegregation on academic achievement has been inadequate, ${ }^{8}$ over the last decade research efforts have increased somewhat. But unless support for continuing research is forthcoming from the federal government and foundations, it is questionable whether there will be significant advances beyond what the studies reviewed in this article have shown.

What can social scientists tell us about the effects of school desegregation on academic achievement? The primary focus of school desegregation research to date has been on the cognitive skills (e.g., reading and mathematics) of nonwhites. The greatest number of such studies report positive gains as a result of desegregation, although it is clear that much additional research is needed before the findings can be fully understood and translated into effective policy. This is due in part to the fact that social scientists' understanding of the learning process is not very well developed, so that explaining the causes of improved pupil performance, even when race is not an issue, is a problematic endeavor. Moreover, some problems arise from the research methodology used; some of these problems are discussed in this article. ${ }^{9}$

There are some social science research findings of the effects of desegregation on the academic achievement of nonwhites, however, about which there is a degree of consensus among social scientists:

6. See Levin, Education, Life Chances, and The Courts: The Role of Social Science Evidence, 39 LAw \& Contemp. Prob. no. 2, at 217 (1975).

7. The most useful analysis in this regard is N. ST. John, School Desegregation Outcomes FOR CHILdRen (1975).

8. A decade ago, a federal official in charge of desegregation enforcement activities replied to a Congressional inquiry about the relative lack of research on desegregation: "The basic problem is there are very few researchers that want to work on it for some reason, but it is a very real problem." Hearings on Guidelines for School Desegregation Before the Special Subcomm. on Civil Rights of the House Comm. on the Judiciary, 89th Cong., 2d Sess. 139 (1966) (testimony of David S. Seeley, then assistant to the U.S. Commissioner of Education, Department of Health, Education, and Welfare).

9. See also Levin, supra note 6. 
1. Of the dozens of studies of the effects of school desegregation on the achievement of nonwhites, only a very few give any indication that placing nonwhites in desegregated schools might lessen their rate of academic achievement.

2. There is virtually no evidence, out of a substantial body of research, that desegregation lowers the achievement levels of whites.

Thus the available research gives little reason to believe that school desegregation, in most settings, will adversely affect the academic achievement of either white or black students. ${ }^{10}$ But will it improve academic performance?

Before attempting to answer this question on the basis of evidence provided by existing research studies, the paramount problem in most of the research should be noted: the difficulty in isolating those factors other than interracial contact that might account for the findings on the effects of desegregation. An important determinant of academic achievement appears to be the home environment. Few studies, however, are able to deal adequately with this factor. Efforts to "control" for the socioeconomic background of children is often used as a surrogate for the student's family situation, but it is not a very precise measure. People from different social classes may have similar attitudes toward education and child rearing. And almost nothing is known about how differences in family attitudes and values relevant to school achievement affect learning within socioeconomic groupings. Another very important factor affecting desegregation studies is the student's academic aptitude.

The studies reviewed in this article come to a variety of conclusions about the effects of desegregated schooling on the academic achievement of black students and other minorities. These studies are categorized on the basis of their conclusions as follows:

1. racial mixing is found to result in a general increase in nonwhite student academic achievement;

2. multiracial schooling is found to have a mixed effect on nonwhite student academic achievement;

3. attendance at racially mixed schools has no apparent effect on student academic achievement;

4. desegregation has negative effects on the achievement gains of nonwhite students.

10. It is possible-if the theory that student culture and teacher expectations are crucial determinants of learning is a valid one-that when the desegregation process results in placing students in settings dominated by low achievers of whatever race, there will be an overall loss in achievement levels. The effects of such situations on individual students will probably depend on the degree to which the student's family and, in later years, his or her immediate peer group, provide support for learning. See, e.g. Hanushek, Teacher Characteristics and Gains in Student Achievement Using Micro-Data, 61 AM. Ecov. Rev. 280 (1971); St. John \& Lewis, The Influence of School Racial Context om Academic Achievement. 19 Social. Problfms 68 (1971); Davis, Busing, in 2 National Opinion Research Center, Southern Schools: An Evaluation of the Effects of the Emergency School Assistance Program and of School Desegregation 83 (1973) [hereinafter cited as Southern Schools]. Robert Crain, study coordinator, however, suggests that Davis's finding may be a function of inadequate controls for the social background of the students. $/ d$. at 116 n. 10 . 
This article reviews some of the more important studies representing each of these categories. In addition, attention is given to research on whether busing itself-with or without desegregation as its purpose-affects learning.

\section{Studies Showing a Positive Effect of Interracial Schooling on Academic Achievement}

One of the most methodologically sophisticated and extensive studies of the effects of school desegregation is the recent evaluation of the Emergency School Assistance Program (ESAP), ${ }^{11}$ published late in 1973. ${ }^{2}$ The ESAP evaluation found that achievement scores of black male high school students who attended schools receiving federal desegregation aid were one-half grade level higher than their peers in other schools. This was attributed by the researchers to "improvements in the [experimental] schools' racial climate affecting the motivation of these students." ${ }^{13}$ Only about half of the between-school variance in achievement was explained by social-class factors. Leadership by principals and teachers was found to be very effective in helping white students accept desegregation. ${ }^{14}$

A similar study ${ }^{15}$ of the effect of school and classroom integration on academic achievement was undertaken in the late 1960's by James McPartland, using Coleman Report data. ${ }^{16}$ This study attempted to answer questions which had arisen in earlier investigations:

1. Do racial effects on achievement persist even after adjusting for differences in social class? Racial classroom desegregation was found to have a positive effect on achievement that is, for the most part, independent of family background.

2. Is there a different racial effect on achievement in desegregated schools as contrasted with desegregated classrooms? "Regardless of the racial composition of the schools, the average achievement level of Negro students increases with the proportion of their classmates who are white." 17 However, "when classroom racial composition as well as family background differences are held constant, there is no evidence that the percent white enrolled in the school has any appreciable influence on Negro student achievement." 18 And "Negro students

11. 20 U.S.C. $\$ \$ 1601-1686(1970)$.

12. See 1-2 Soutreri Schools.

13. I SOUTHERN SChOOLS iv.

14. See Orfield, How to Make Desegregation Work: The Adaptation of Schools to Their Newly Integrated Student Bodies, 39 Law \& Contemp. Prob. no. 2, at 314 (1975).

15. See J. McPartland. The Relative Influence of School Desegregation and of Classroom Desegregation on the Academic Achievement of Ninth Grade Negro Students. September 1967 (unpublished document on file with the Center for the Study of Social Organization of Schools at Johns Hopkins University). This study utilized achievement test scores derived from 5,075 Negro ninth-graders in New England and Middle Atlantic states.

16. J. Coleman, kquality of Educational OpPortunity (1966).

17. J. McPartland, supra note 15, at 3.

18. Id. at 4. A study of six schools in Tacoma. Washington between 1963 and 1967 at a time 
who remain in segregated classes in a 'desegregated' school receive no benefit in terms of their academic growth." Indeed, McPartland found that "segregated classes may be more detrimental for Negro student achievement if they occur in mostly white schools rather than mostly Negro schools."19

3. Are racial effects on achievement simply artifacts of ability grouping procedures? Matzen, in his San Francisco Bay area study, ${ }^{20}$ found that ability grouping accounted for a good deal of what appeared to be racial differentials in achievement. While McPartland also found that school selection processes play a role, it was a distinctly minor one. He concluded, therefore, that the desegregative effect on classroom achievement could not be explained by the schools' selection processes, and that race was an autonomous factor. ${ }^{21}$

Under the auspices of the United States Commission on Civil Rights, McPartland, with Robert York, reanalyzed some of the Coleman Report ${ }^{22}$ data in an effort to separate the effects of race from that of social class upon achievement scores. ${ }^{23}$ The study concluded that "there is a positive association of achievement scores with the racial composition of the classroom, no matter what the racial composition of the school may be." 24 Even when "holding constant the social class of the student and his school-there remains an upward

when the percentage of black enrollment city-wide went from 6.6 per cent to 8.9 per cent-where the school was the unit of analysis rather than the classroom-showed little evidence of a racial effect on achievement. J. Laurent, Effects of Race and Racial Balance of School on Academic Performance, 1969 (unpublished doctoral dissertation at University of Oregon). See also J. Laurent, Do Pupil Race andor School Racial Balance Affect Academic Performance? (1970).

19. Id.

20. See discussion at pp. 254-55 infra.

21. It should be noted that McPartland's study was cross-sectional, not longitudinal, meaning that it was based on data collected at one point in time. Longitudinal studies are those which include at least two sets of data gathered over a period of time. Usually the data show the changes in a particular characteristic or phenomenon over time. At best, then, McPartland's data suggest relationships in interracial classrooms, irrespective of whether the classroom had ever been anything but interracial.

22. The Coleman Report had been released in 1966 . With respect to achievement, it made the following findings:

1. [A]s the proportion white in a school increases, the achievement of students in each racial group increases.

2. [T] his relationship increases as grade in school increases.

3. The higher achievement of all racial and ethnic groups in schools with greater proportions of white students is largely, perhaps wholly, related to effects associated with the student bodys educational background and aspirations [rather than with better facilities and curriculum].

4. [A]verage test performance [for Negroes increases] as the proportion of white classmates increases....

5. Those students who first entered desegregated schools in the early grades do generally show slightly higher average scores than the students who first came to desegregated schools in later grades.

J. Coleman, supra note 16 , at 307,321 .

23. See 2 U.S. Commission on Civil Rights, Racial Isolation in the Public Schools 35 (1967).

24. Id. at 38 . 
trend in average achievement level [of blacks] as the proportion of white classmates increases." 25

McPartland and York suggest two reasons for the apparent inconsistency between their findings and those of the Coleman Report on this point: (1) the statistical techniques used in the earlier study tended to confuse social class and race; and (2) the Coleman Report, in the regression analyses, used the school rather than the classroom as the unit of analysis. Yet, the authors stress that "it is in the classroom within the school where the characteristics of the fellowstudents have their effects." 26 Negro students in a segregated classroom, for example, do not benefit even if the school as a whole is racially balanced. The research design employed in the Coleman Report did not permit this kind of distinction to be made.

Several studies relating higher achievement of black students to attendance at non-segregated schools were completed in 1971 by Nancy St. John. ${ }^{27}$ Black ninth-graders in the city of Pittsburgh who had attended non-segregated elementary schools for a large part of their early education showed higher achievement scores in mathematics than black students who had attended segregated schools. She also found that the academic success of these black children was dependent to a significant degree upon social acceptance by white classmates. Thus, concludes St. John, optimistic and skilled guidance by an understanding teacher is crucial in the non-segregated school. St. John came to parallel conclusions following a study in Boston. ${ }^{28}$ She and Lewis studied 908 white and black sixth-graders in eighteen different schools, distributed among thirty-six classrooms. A positive association between increased achievement of blacks in arithmetic and the school's percentage of white enrollment was found, with black pupils achieving greater gains if their schools were majority white. ${ }^{29}$

James Fortenberry studied Negro achievement in Oklahoma City, comparing the achievement scores of a sample of eighth and ninth grade Negro students with their sixth grade scores. ${ }^{30}$ Some of the children had never attended a desegregated school, and others had attended segregated schools through the sixth grade but were placed in a desegregated school for the seventh and eighth grades. All of the students had had statistically similar achievement test scores in sixth grade. By eighth grade, students in racially mixed classes had significantly improved their performance in arithmetic compared to those in segregated schools, although there was no difference in performance on reading achievement tests. By ninth grade, children in mixed

\footnotetext{
25. Id. at 40 .

26. Id. at 42 .

27. See N. St. John, School Integration, Classroom Climate, and Achievement (1971).

28. See St. John \& Lewis, supra note 10.

29. Id. at 71 .

30. See J. Fortenberry, The Achievement of Negro Pupils in Mixed and Non-Mixed Schools, 1959 (unpublished doctoral dissertation at University of Oklahoma).
} 
classes scored higher in arithmetic and language expression achievement tests, while the children in segregated classes scored higher in reading achievement. Fortenberry's overall conclusion was that "in general, Negroes achieve better in mixed than in non-mixed classes." 31

A study which compared the achievement of black students in racially balanced and imbalanced schools in a city in upstate New York showed no significant differences in achievement by type of school attended. But when students who had attended these schools for two years or longer were examined separately, significantly higher achievement scores were found among children who attended racially balanced schools. ${ }^{32}$

In an ongoing longitudinal study of 316 Negro and 501 white students attending six schools in two cities, one in the West and one in the Midwest, Michael Rosenfeld reported that while Negro students scored lower on the achievement tests administered, "there were tests in the battery and time periods during which Negro and white students grew at the same rates when initial differences between the two groups were taken into account." ${ }^{33}$

Robert Frary and Thomas Goolsby studied the effects of compensatory education on black children in segregated and non-segregated settings in Gulfport, Mississippi. ${ }^{34}$ Twenty classrooms of first-graders were involved, ten experimental and ten control groups. Children in the experimental classes were assigned at random; they also came from poorer homes than black children in the control group. Children in the non-segregated group gained significantly more than those in segregated classes. ${ }^{35}$ Children who had scored low on the Metropolitan Readiness Tests responded especially well to the special instructional measures of the compensatory education program. Indeed, "the achievement scores of the low readiness, integrated Negroes exceed those for either white group in spite of a much lower mental age mean . . ."36 Goolsby and Frary warn of the depressive effect on low readiness children of being placed in a segregated classroom. In such settings "very low achievement may become the accepted norm." 37

Seventy-five Negro fourth, fifth, and sixth grade students in five desegregated schools in Nashville were compared with a like number from three all-

31. Id. at 44 .

32. See J. Lockwood, An Examination of Scholastic Achievement, Attitudes and Home Background Factors of Sixth-Grade Negro Students in Balanced and Unbalanced Schools, 1966 (unpublished doctoral dissertation at University of Michigan).

33. M. Rosenfeld, Negro and White Differences in Intellectual Growth 6 (1968) (emphasis added).

34. See Frary \& Goolsby, Achievement of Integrated and Segregated Negro and White First Graders in a Southern City, 8 Integrated Ed. 48 (July-Aug. 1970).

35. T. Goolsby \& R. Frary, Enhancement of Educational Effect Through Extensive and Intensive Intervention: The Gulfport Project 41, 56, July 1969 (unpublished document on file with the Gulfport Municipal Separate School District, Gulfport, Miss.).

36. Id. at 50 .

37. Id. at 52 . 
Negro schools. ${ }^{38}$ The former, who constituted from 8 to 33 per cent of enrollment in their schools, had attended desegregated schools for up to six years. All children in the sample were from the same neighborhoods. Academic achievement was found to be significantly higher among students attending the desegregated than the segregated schools. Children who entered a desegregated school near the beginning of their school career achieved significantly better than segregated pupils. On the other hand, children who were not desegregated until the fifth or sixth grade achieved less than did Negro children in the segregated schools. However, the significance of this research is difficult to gauge because even though students came from similar neighborhoods, no explicit controls for social class were employed.

A study was conducted of New Rochelle schools after approximately 50 per cent of the enrollment of an all-Negro elementary school was transferred to several predominantly white schools. ${ }^{39}$ After one year, achievement tests were administered to all of the Negro transferees. Achievement test score changes for students in grades one through five were found to be statistically insignificant. ${ }^{40}$ To determine the effect of social class, average reading scores of both Negro transferees and those who remained in the all-Negro school were compared with those of the white children in the receiving school; the latter were significantly higher, despite the fact that the white students were of the same social class background as the Negro children. ${ }^{41}$ An analysis of achievement gains among black kindergarten children showed a statistically significant change after a year of desegregated education. Gains of this group exceeded those of the Negro non-transferees and the whites in the receiving schools. The study suggests that this is evidence of the importance of early intervention. " $[E] x p o s u r e$ to favorable learning circumstances at an early enough age can have a salutary and compensatory effect on the educational potential of minority and otherwise deprived children." 42 Unfortunately, no statistical data are presented in the article so that it is not possible to fully assess this research.

A study was undertaken in Richmond, Virginia to determine whether the academic program of black students who graduated from a segregated junior high to a non-segregated senior high school would suffer. The study found no impairment of their academic progress. ${ }^{43}$

A study of 883 eighth-graders in southern schools, some of whom had

38. See L. Anderson, The Effects of Desegregation on the Achievement and Personality Patterns of Negro Children, 1966 (unpublished doctoral dissertation at George Peabody College for Teachers, Nashville, Tenn.).

39. See Wolman, Learning Effects of Integration in New Rochelle, 2 INTEgRated Ed. 30 (Dec. 1964-Jan. 1965).

40. See id.

41. Id. at 30-31.

42. Id. at 31 .

43. See L. Savage, Academic Achievement of Black Students Transferring from a Segregated Junior High School to an Integrated High School, July 1971 (unpublished master's thesis, at 
attended desegregated schools for some time and others who entered such schools only during the year of the study (1970-71), reported that the scores of black students increased significantly in both reading and arithmetic. ${ }^{44}$ In terms of grade-equivalents, black students gained .91 and white students 1.07 on the Iowa tests. As is true of so much of this kind of research, the reasons for success in this project were not immediately apparent. The study concludes, however, that "[i]t makes little difference whether academic improvement by the students can be attributed primarily to the desegregation of the races; of primary importance is that under a desegregation plan these schools have been able to provide conditions that facilitated academic improvement for all students." 45

Several studies of the effects of desegregation on pupil achievement have been undertaken in North Carolina. In one study, student achievement in grades five, seven, and nine in a desegregated school in Chapel Hill were compared with achievement in segregated schools. ${ }^{46}$ Negro achievement rose significantly in mathematiçs at grades five and seven; and for white students, at grade five. Reading scores did not show any significant increase, however. Two separate studies of desegregation in Goldsboro, North Carolina showed significant gains for black students in both reading and mathematics. ${ }^{47}$

A study in New Albany, Indiana was undertaken to determine whether school learning proceeded at comparable rates for Negro and white children when children were not desegregated until they reached junior high school and for Negro students in desegregated schools compared with those in segregated schools ${ }^{48}$ - controlling for such variables as socioeconomic status and intelligence. In the first comparison, Negro and white students were matched and their academic achievement over two years was compared, using both achievement tests results and classroom grades. In the second comparison, two groups of Negro students were the subjects: one consisted of children who had attended a segregated school and the other of children who had been

Virginia State College). A control group of students who attended a black senior high school was utilized in this study.

A number of studies showing positive achievement gains from desegregation are collected in Pettigrew, Useem, Normand, \& Smith, Busing: A Review of "The Evidence," 30 Pub. InTEREST 88 (Winter 1973). A study conducted in Berkeley, California concluded that achievement gains of students were greater from a desegregation program than from a compensatory program. This was true, apparently, even though desegregation was accompanied by a reduction in school services. $I d$. at 98 .

44. See W. Howell, The Correlates of Change in School Integration with the Academic Achievement of Eighth Grade Students, 1972 (unpublished doctoral dissertation at University of

South Carolina).

45. Id. at 48 .

46. Prichard, Effects of Desegregation on Student Success in the Chapel Hill City School, 7 INTEGRATED ED. 33 (Nov.-Dec. 1969).

47. Pettigrew, Useem, Normand, \& Smith, supra note 43, at 94.

48. See I. Samuels, Desegregated Education and Differences in Academic Achievement, 1958 (unpublished doctoral dissertation at Indiana University). 
desegregated in junior high school. It was found that after two years of desegregation, the achievement gap between Negro and white students had narrowed significantly. This was attributed directly to desegregation. The study also found that Negro children who attended interracial elementary schools started out in first grade achieving at the same level as did Negro children in the segregated school. By third grade, however, the desegregated Negro children had pulled ahead; this continued into sixth grade. Overall, the study concludes that: ${ }^{49}$

$[T]$ he longer the association between any particular group of white and Negro students the smaller the differences in academic achievement appear to be . . . and that the Negro students who had been educated in mixed schools achieved as well as and sometimes better than white students in the integrated program.

The achievement scores of sixty-four black children whose all-black school in Tulsa, Oklahoma was closed in 1968, requiring them to be transferred to a non-segregated school, were analyzed. On five of six sub-tests of the Stanford Achievement Test, as well as on IQ tests, the transferred children scored significantly higher than the "control" group-a matched group in an all-black school. While the transferred students earned lower grades than children in the control group, they nevertheless had a more positive attitude toward school than did the control group..$^{50}$

Desegregation of the schools in Riverside, California has been the subject of a number of studies. One significant study investigated the development of cognitive skills during the first year of desegregation. The researcher found that the higher IQ and reading scores in the desegregated sample were accounted for by increases in Anglo scores only. ${ }^{5}$. Achievement tended to rise in proportion to the duration of desegregation. With implications for ability grouping, the study further noted that: ${ }^{52}$

In tallying the results for the primary grades, the writer was impressed several times to find that groups of integrated pupils achieved at different levels according to the level of the children with whom they were grouped. Children with equal or lower IQ's scored higher on the reading tests when they were scattered severally among the classes in the receiving school, rather than clustered together in one or two groups.

Florence Denmark conducted a study in Manhasset, New York which found that social interaction between black and white children improved the verbal ability test scores of the black children. ${ }^{53}$ As other researchers have also noted,

49. Id. at 100 .

50. See J. Griffin, The Effects of Integration on Academic Aptitude, Classroom Achievement, Self-Concept, and Attitudes Toward the School Environment of a Selected Group of Negro Students in Tulsa, Oklahoma, 1969 (unpublished doctoral dissertation at University of Tulsa).

51. See M. Purl, Progress Report No. 4, Oct. 15,1968 (unpublished document on file with Riverside Unified School District, Riverside, Cal.).

52. Id. at 2 1. See also Wicker, Integration and Innovation. N.Y. Times, Apr. 2. 1974, at 39, col. 1.

53. See Denmark, The Effect of Integration on Academic Achievement and Self-Concept, 8 INTEGRATED ED. 34 (May-June 1970). 
Denmark found that teachers in desegregated schools did not give full recognition to the extent of the progress the black students had made because of the higher standards these teachers had compared to those of teachers in the segregated environment. Thus, black students might be learning that improved academic performance does not bring increased rewards.

Several studies of school desegregation are of small-scale, voluntary programs. One such program is Project Concern, a program involving the placement of inner-city minority children in suburban schools in various areas in Connecticut. Five studies have been made of various components of Project Concern. The academic achievement of minority students attending kindergarten through grade five-a year after the program was initiated-was studied by Bruce Wood, who selected a control group which matched the Project Concern students in WISC-Verbal IQ scores. ${ }^{54}$ A summary of Wood's findings shows the following: ${ }^{55}$

Grades $K-1$ : Achievement scores in arithmetic, vocabulary, and verbal $1 Q$ increased.

Grades 2-3: Total performance on IQ tests increased significantly.

Grades 4-5: Vocabulary score increased significantly; while gains were not sweeping, the overall direction was clear. The achievement gains of white children in the receiving schools were not affected.

A study of Hartford, Connecticut, two years after the implementation of Project Concern, was undertaken by Aline and Thomas Mahan. ${ }^{56}$ Black students in grades K-3 were found to have "significantly different (and higher) scores on measures of mental ability and achievement generally." ${ }_{57}$ More significant, however, was the fact that the cognitive functioning of the Negro children improved in general. ${ }^{58}$

The direction of this impact is toward greater verbal productivity, increased accuracy in the associative and sorting processes, and an enhanced willingness to take a risk in terms of verbal responses to situations ... . There are indications that there is a tendency toward better understanding of expectations (i.e., better test-taking skill), increased self-discipline, and increased ability to evaluate responses in terms of external standards.

An investigation of the Project Concern experience in suburban Cheshire, Connecticut, undertaken by Marilyn Levy, involved only twenty-five students, probably all from New Haven. ${ }^{59}$ No significant changes in average achievement

54. See B. Wood, The Effects of Busing Versus Non-Busing on the Intellectual Functioning of Inner City, Disadvantaged Elementary School Children, 1969 (unpublished doctoral dissertation at the University of Massachusetts).

55. Id. at 60-66.

56. See Mahan \& Mahan. Changes in Cognitive Style: An Analysis of the Impact of White Suburban Schools on Inner City Children, 8 INTEGRATEd ED. 58 (Jan.-Feb. 1970).

57. Id. at 60 .

58. Id.

59. See Cheshire Dep't of Education, Project Concern in Cheshire: A Preliminary Report 
scores were recorded. On the other hand, over the same twelve month period, the per cent of children scoring above grade-level rose from thirty to fifty-two. The explanation for these varying results is not clear. A study of 196 Project Concern children from Hartford, conducted by Aline Mahan over a two year period, showed more positive results. ${ }^{60}$ In the suburban schools, the relationship between social acceptance and achievement was significantly stronger than in the schools of Hartford. Mahan reported that being in a high-achieving classroom helps, even if the school is in the inner city-although the impact is much greater when the school is in the suburbs. A study of 138 New Haven Project Concern children also found greater gains in reading among such children than were found in two comparable groups of students not part of Project Concern. ${ }^{61}$

Three studies have been undertaken in different areas of Florida, two of which show a strong relationship between desegregation and Negro achievement. The third, showing mixed results, is described in the next section of this article. ${ }^{62}$ An investigation into the impact of desegregation on black students in Brevard County, Florida ${ }^{63}$ showed that while Negro students attending desegregated schools scored lower than their white classmates on five out of six measures of achievement, they scored significantly higher than the Negro students who remained in the segregated high school. ${ }^{64}$

The second study involved students in the fourth, sixth and eighth grades in a northwestern urban county of Florida between 1966 and $1967 .{ }^{65}$ After one academic year, black students in desegregated schools had significantly higher achievement scores than a comparable group of students who remained in segregated schools. The test-anxiety level of both groups of black students was similar, however. ${ }^{66}$

An evaluation of a voluntary busing project in Boston, Massachusetts, known as Operation Exodus, was undertaken by James Teele. Teele's sample

(1970), in Hearings on Equality of Educational Opportunity Before the Senate Select Comm. on Equal Educational Opportunity, 91 st Cong., 2d Sess., pt. 1B, at 590 (1970).

60. See A. Mahan, Social Factors and the Academic Success of Urban Children, 1969 (unpublished doctoral dissertation at the University of Connecticut).

61. See J. Samuels, A Comparison of Projects Representative of Compensatory, Busing, and Non-Compensatory Programs for Inner-City Students, 1971 (unpublished doctoral dissertation at the University of Connecticut). See also Samuels, Busing, Reading, and Self in New Haven, 10 INTEGRATED ED. 23, 24-28 (Nov.-Dec. 1972).

62. See discussion at pp. 253-60 infra.

63. See F. Williams, An Analysis of Some Differences Between Negro High School Seniors from a Segregated High School and a Nonsegregated High School in Brevard County, Fla., 1968 (unpublished doctoral dissertation at the University of Florida).

64. Id. at 44-53. At the start of the 1964-65 school year, white and Negro students attending segregated high schools took a statewide ninth grade achievement test. In 1965 the white high school was desegregated and a group of Negro students were enrolled in that school. In 1967-68, the same students took the twelfth grade achievement test.

65. See T. Starnes, An Analysis of the Academic Achievement of Negro Students in the predominantly White Schools of a Selected Florida County, 1968 (unpublished doctoral dissertation at the University of Southern Mississippi).

66. Id. at 26 
consisted of approximately 600 black students with a control group of children who remained in all-black schools. ${ }^{67}$ The data suggest that the longer the minority students participated in Operation Exodus, the more likely it became that their reading achievement would improve significantly. ${ }^{68} \mathrm{Just}$ as important, the black child's feeling of being accepted increased. ${ }^{69}$ The two factors of achievement and acceptance seem, according to Teele, also to be closely interrelated, suggesting that " $[\mathrm{t}]$ hose planning school integration programs for black children should be at least as concerned with issues and conditions of emotional and social development as they are with issues of cognitive development." 70

Some studies have found that the beneficial effects of attending nonsegregated schools extend beyond in-school academic achievement. Robert Crain found a substantial impact on achievement scores of blacks who attended non-segregated schools, even after allowing for socioeconomic differences. ${ }^{71}$ In part, the beneficial outcome resulted from more resources and association with larger numbers of students in higher socioeconomic classes in the nonsegregated schools. But in addition, Crain suggests that black students learn what "it means to live in a white man's world," 72 which stimulates the black child to higher achievement. A further analysis indicated that in addition to improving their academic achievement, black students in a non-segregated setting were more likely to complete high school, attend college, and enter occupations customarily closed to blacks. ${ }^{73}$ For northern blacks, attendance at nonsegregated schools also was associated with increased level of home ownership, financial responsibility, and job stability. Furthermore, these findings are not the result of higher socioeconomic background. "[S] urprisingly, black students in integrated schools do not come from higher-status families than those in segregated schools." 74

II

\section{Studies Showing Mixed Effects of Interracial Schooling on ACademic Achievement}

A sizable number of studies of the impact of desegregation on academic achievement have shown mixed and ambiguous results. In part, this can be attributed to inadequacies in the methodology. But part of the ambiguity is also due to the fact that we have no well-developed theory of learning which would permit us to interpret and explain some of the results. This section of

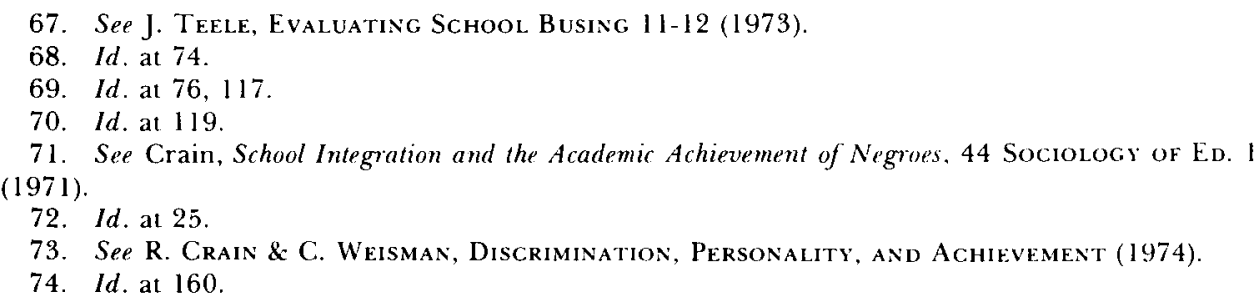


the article describes some of these mixed studies and, where feasible, suggests some of the missing factors which may explain these results.

A major study of the effect of racial composition upon achievement in the San Francisco Bay area, undertaken by Stanley Matzen, analyzed the relationship between the proportion of Negro students in a classroom and the average academic achievement of Negro and non-Negro students. ${ }^{75}$ The findings were as follows:

1. In general, there was a tendency for achievement to vary inversely with the percentage of Negro students in the classroom. There were some "notable exceptions," however. Of twenty-one fifth grade classrooms, data for five showed exceptional trends. For example, thirty-one students in one classroom were below average in achievement and IQ scores, and had fewer Negroes than the average classroom. Another classroom was considerably above average in IQ score, below average in achievement, and very high in percentage of Negro students. Much of the negative relationship between per cent Negro and Negro achievement may be attributable, according to this study, to the practice of classroom grouping. Relatively few high-achieving Negroes, for example, will be placed in classrooms with high-achieving whites. Thus, the author argues, the result is a more negative relationship between race and achievement than might otherwise be found.

2. $1 Q$ like achievement, tended to vary inversely with the percentage of Negro students. The report points out, however, the presence of "numerous exceptions" and characterizes the relationship between the two variables as "far from perfect."76

3. Achievement varied directly with socioeconomic status. While the entire student sample was heavily lower class, over half the fifth graders achieved above grade level. Only one-third of the seventh graders were above grade level.

4. When IQ and socioeconomic status were held constant, achievement tended to fall as the percentage of Negroes rose, but the tendency was not strong enough to be of statistical significance. Thus per cent Negro turned out not to be a depressive factor in itself, but only when combined with low socioeconomic status and low IQ. Yet, the percentage of Negro students in the classroom and achievement scores were differently related in fifth grade than in seventh grade. One possible reason offered in the report is a difference in classroom grouping practices. In the fifth grade, students were much less homogeneously grouped than in seventh grade; therefore, Negro-white differentials were greater in grade five.

75. See S. Matzen, The Relationship Between Racial Composition and Scholastic Achievement in Elementary School Classrooms, 1965 (unpublished doctoral dissertation at Stanford University). Eleven hundred students in eleven schools in the San Francisco Bay area were tested. The tests were administered to fifth and scventh grade Negro and Caucasian students in the fall of 1963. Findings were reported in terms of four major relationships: (1) per cent of Negroes in the classroom and achievement; (2) per cent of Negroes and average intellectual ability; (3) average intellectual ability and achievement; and (4) socioeconomic status and achievement.

76. Id. at 42 . 
In grade seven, on the other hand, grouping was quite homogeneous with higher-achieving Negro children being placed in classrooms with higherachieving white children. Negro-white differences were thus minimized. In other words, in the fifth grade, one was likely to find equal numbers of Negroes and whites in the low-scoring as in the high-scoring classrooms. In the seventh grade, high-scoring whites tended to be in one classroom, and lowscoring Negroes in another one. In the latter case, the negative reaction between per cent Negro and achievement scores was high; in the former case, it was low.

It is quite possible to interpret these findings as indicating that the presence of Negroes must be minimized if achievement is to be maximized. Matzen provides an alternative explanation: that a new variable " $E$ Q" (educational quality) be constructed, which would be comprised of indices of teacher competence and motivation, quality of textbooks and other instructional materials, enrichment-value of the classroom and school environment, and similar determinants-in terms of school resources-of how much pupils learn. ${ }^{77}$ Matzen hypothesizes that $\mathrm{E} Q$ would be found to be negatively correlated with the percentage of Negro students, and positively related to IQ scores, achievement scores, and socioeconomic status. ${ }^{78}$ In short, with schools of equal quality, the per cent of Negroes in a classroom might no longer have a negative effect on achievement.

A study of Negro and white pupils in the public schools of Jackson, Michigan was designed to determine the effect of social interaction on achievement. ${ }^{79}$ The hypothesis to be tested by the research was that "the measured intelligence of the group of Negro children will be significantly changed as the consequence of school experience which enhances their opportunities for social interaction with the dominant white culture." 80 All children-which included 193 Negroes and 1,061 whites-who entered kindergarten in the fall of 1957 and of 1958 were given standard intelligence tests. The children were then retested in the second grade, during the fall of 1959 and of 1960 . The Negro students were treated as an experimental group and the whites as a control. ${ }^{81}$ Average IQ scores were as follows: ${ }^{82}$

$\begin{array}{lrr} & \frac{1957-1958}{83.06} & \frac{1959-1960}{89.74} \\ \text { Experimental group (Negro) } & 102.04 & 103.91\end{array}$

77. Id. at 114 .

78. Id. at 115 .

79. See W. Katzenmeyer, Social Interaction and Differences in Intelligence Test Performance of Negro and White Elementary School Pupils, 1962 (unpublished doctoral dissertation at Duke University).

80. Id. at 9 .

81. A more appropriate methodology or research design would have been to match the experimental group with a control group of Negro children.

82. W. Katzenmeyer, supra note 79 , at 57-58. 
The study concluded that the change in IQ of the experimental group could be explained principally by the social interaction between Negro and white children. In Jackson, "the great majority of the Negro population is confined to a small area of the city by economic limitations and by discriminatory policies and pressures in the sale of real estate. . . Thus, for most Negro children, entry into the racially mixed public school program represents the beginning of a period of increased social contact." ${ }^{83}$ Another part of the explanation is the high per pupil expenditure in Jackson schools. Presumably, the Negro child, more deprived to begin with, benefited more from the increase in educational resources. ${ }^{84}$ The report concludes that:

$[W]$ hile the implications of this study point to some of the disadvantages of segregated schools, they suggest that the answer to the equalization of educational opportunities lies only partially in "integration" per se; they suggest that a problem basic to the school lies in guiding and encouraging the assimilative process.

A second Michigan study was of black children in Grand Rapids who were being bused to white schools. ${ }^{86}$ Those children who were bused for two years registered significantly higher gains in arithmetic than did students who were bused only one year; and, in turn, the students bused for one year showed significantly higher gains than those who were not bused at all. No reading achievement effect was apparent for either group of bused children. ${ }^{87}$

A three-year program in Evanston, Illinois was evaluated by Jayjia Hsia, who found that, on the whole, achievement of black children did not improve significantly. However, a number of special situations were found to relate to academic growth: fourth grade students who were bused to school gained significantly over those who walked to a new school; fifth grade students who remained in their non-segregated neighborhood school registered higher gains than students transferred to a new school, regardless of whether they walked or were bused there ${ }^{88}$ Comparisons are especially difficult to make in the Evanston study because data on the socioeconomic status of students were not used in the analysis.

First grade minority children from Newark, New Jersey who participated in

83. Id. at 64

84. Id, at 67 .

85. Id

86. See W. Scot, A Study of Bused and Non-Bused Children, June 1970 (unpublished document on file with the Grand Rapids Public School System, Grand Rapids, Mich.).

87. Id. at 3 .

88. See J. Hsia, Integration in Evanston, 1967-71: A Longitudinal Evaluation, August 1971 (unpublished document on file with Educational Testing Service. Princeton, N.J.). For a negative evaluation, see Kurtz, An Independent Assessment of Integration in Euanston, 1967-1971: A Longitudinal Evaluation: A Report on the Educational Consequences of Desegregation in District 65 of Evanston, Ill., in Hearings on School Busing Before Subcomm. No. 5 of the House Comm. on the Judiciary, 92nd Cong., 2d Sess., pt. 3. at 1436-43 (1972). 
a voluntary busing plan to Verona, a suburb of Newark, scored significantly higher on achievement tests than their peers who remained in schools in the inner city. Second-graders, however, failed to register such gains. ${ }^{89}$ In neither case are data on family background of bused and non-bused students provided.

The impact of open enrollment on an upper-middle to middle class white K-5 school in New York City was investigated in $1969 .{ }^{90}$ Ninety-five black children were bused to a school with a white enrollment of 1,005 students. The evidence indicated that academic achievement levels of both the bused children and the children in the receiving school did not drop as a result of the program; nevertheless, many of the white parents in the area were convinced of the opposite. The teachers in the receiving school also tended to underestimate the performance levels of the black children. The children, however, had little doubt of the value of the new school. In the researcher's interviews with twenty of them, they expressed the following typical evaluations: "We learn more .... Most of the time in the other school we do easy phonics, easy math, easy everything. ... In this school, the teachers know more .... We didn't do no work there." 91

The impact of desegregation on achievement was investigated in a small urban area within the New York City metropolitan area. ${ }^{92}$ Black children who had attended a non-segregated school since kindergarten had a markedly more favorable attitude toward school than their white peers. Black and white children of the same IQ level scored comparably well in reading tests, regardless of whether they had attended a non-segregated school since kindergarten or since second grade. ${ }^{93}$ One implication of this latter finding is that achievement effects of desegregation may not depend upon the earliest possible but only early attendance in a desegregated school.

The effect of school pairing on achievement has also been studied in New York City. ${ }^{94}$ Negro students in the paired schools scored significantly higher on arithmetic achievement tests than did Negro students in a segregated school. No significant differences between the two groups of students showed up in any other achievement measures, however. White children in the paired schools continued to learn at their previous rates.

89. Zdep, Educating Disadvantaged Urban Children in Suburban Schools: An Evaluation, 1 J. A PPLIED Social Psychology 173, 180 (1971).

90. See B. Brooks, A Study of Ninety-Five Children Traveling by Bus to a K-5 School as Part of the Open Enrollment Program in a Large Urban School System, 1969 (unpublished doctoral dissertation at Columbia University).

91. Id. at $95-97$.

92. See M. Moreno, The Effect of Integration on the Aptitude, Achievement, Attitude to School and Class, and Social Acceptance of Negro and White Pupils in a Small Urban School System, 1972 (unpublished doctoral dissertation at Fordham University).

93. Id. at 76 .

94. See I. Slone, The Effects of One School Pairing on Pupil Achievement, Anxieties, and Attitudes, 1968 (unpublished doctoral dissertation at New York University). 
During the 1971-72 school year, the elementary schools of Fort Worth were desegregated by federal court order. ${ }^{95}$ Black fifth graders who attended newly-desegregated schools were found to have made significantly higher gains in reading and arithmetic than did their peers in predominantly black neighborhood schools. Desegregated black fourth-graders, however, showed no such achievement gains. ${ }^{96}$ The achievement record of white students who attended formerly majority-black schools was compared to that of their peers who continued in neighborhood schools; no difference was found. ${ }^{97}$ In a separate report on the 1972-73 school year, the same researcher found significantly greater achievement for bused black students than for their peers who remained in majority-black neighborhood schools. In addition, he found this advantage applied not only to fourth-graders but to black children in the third and fifth grades as well. ${ }^{98}$

San Francisco is a multiracial city but it did not desegregate all its elementary schools until $1971-$ when it did so under court order. ${ }^{99}$ Following a year of planning, one area had been desegregated the year prior to the court order. Of the minority students in this area, who had thus experienced one more year of desegregation than minorities in the rest of the school district, blacks and Orientals showed greater gains in math, but Spanish-speaking and Filipino students did worse. ${ }^{100}$ On the other hand, Spanish-speaking students from those schools that had been desegregated for the additional year made greater gains in reading. All other minorities from the prior desegregated area, with the exception of the Chinese students (who were unaffected), showed fewer gains in reading than did minority students from other parts of the city. Again, no controls for social class or the previous achievement levels of individual students were apparently employed.

Two studies of "one-way" busing programs were undertaken in Buffalo, New York. The first study found that black students who were bused to a predominantly white school had a much higher rate of academic achievement than did their peers who remained at the all-Negro school. ${ }^{101}$ The researchers reported, however, that in classrooms where the racial composition exceeded 30 per cent black, the achievement levels were no higher than those in an

95. See Flax v. Potts, 464 F.2d 865 (5th Cir. 1972).

96. See C. Evans, Short-Term Desegregation Effects: The Academic Achievement of Bused Students, 1971-1972, January 1973 (unpublished document on file with Fort Worth Independent School District, Fort Worth, Tex.).

97. Id. at 23 .

98. See C. Evans, Integration Evaluation 2, August 15, 1973 (on file with Forth Worth Independent School District, Fort Worth, Tex.).

99. Johnson v. San Francisco Unified School Dist., 339 F. Supp. 1315 (N.D. Cal. 1971), vacated and remanded for further findings, 500 F.2d 349 (9th Cir, 1974).

100. See San Francisco Unified School District, Evaluation of San Francisco Unified School District Desegregation Data from Integration 1971-72, at 36, 38, 56, \& 58, October 1972 (unpublished document on file with San Francisco Unified School District, San Francisco, Cal.).

101. See R. Banks \& M. Di Pasquale, A Study of the Educational Effectiveness of Integration, January 1969 (unpublished document on file with Buffalo Public School System, Buffalo, N.Y.). 
all-black classroom. However, insufficient information was supplied-e.g., the socioeconomic status of the white children in predominantly black classrooms-to adequately evaluate this research.

The second study followed the desegregation process in six schools in Monroe County over the period September 1, 1967 to June, 1970 which were involved in a voluntary one-way busing project in which minority students from Buffalo were transported to predominantly white schools in the county. ${ }^{102}$ The study found that ${ }^{103}$

[d]isadvantaged Negro pupils in compensatory and integrated classes for the same time showed similar outcomes in scholastic development. Similar pupils enrolled in segregated classes where no major efforts were directed toward remediation, enrichment, or integration were significantly lower [in academic achievement] than those who had these scholastic experiences.

Also, the earlier that students were enrolled in compensatory or other similar programs, the greater the achievement levels were. Achievement gains were not found to be incompatible with segregation. On the other hand, attendance in enriched classes which were segregated was not as beneficial as either desegregation or compensatory education-i.e., a comprehensive program of remediation. The researcher concluded that educational planners should seek to combine desegregation with compensatory educational programs as the best overall strategy for educational success.

Several evaluations of the desegregation process in Rochester, New York showed that white students in schools to which blacks were reassigned continued to learn at their customary rate. ${ }^{104}$ Within the same school, a significant learning advantage accrued to students in integrated rather than in segregated classes. On the other hand, and contrary to findings as to the impact the previous year, integrated classes did not continue to show achievement superiority over segregated classes with a component of compensatory education, a finding similar to that of the Buffalo study. ${ }^{105}$ A report the following year reached the same conclusion: that blacks in segregated settings did not have the achievement gains that children in desegregated classrooms had. Whether a black child attended a desegregated school near his own neighborhood, whether he was bused to a desegregated school near his own neighborhood, or whether he was bused to a desegregated school in the suburbs made no difference in his academic achievement gains. ${ }^{106}$

102. See O. Bowman, Scholastic Development of Disadvantaged Negro Pupils, 1973 (unpublished doctoral dissertation at State University of New York at Buffalo).

103. Id. at 85 .

104. See H. Goldberg, J. Griffith, R. Green, \& O. Bowman, An Interim Report on a Fifteen Point Plan to Reduce Racial Isolation and Provide Quality Integrated Education, July 1969 (unpublished document on file at the Rochester Board of Education, Rochester, N.Y.).

105. O. Bowman, supra note 102.

106. Division of Planning and Research of Rochester City School District, A Three Year longitudinal Study to assess a Fifteen Point Plan to Reduce Racial Isolation and Provide Quality Integrated Education for Elementary Level Pupils (1970). 
In Syracuse, a group of Negro children were bused from a segregated school-Croton Elementary-to a predominantly white school-Edward Smith Elementary School. At the end of the school year, white children at Edward Smith showed their customary achievement gains, but the minority children who were transferred to Edward Smith failed to increase their academic achievement levels any more than the black children who had remained at Croton. ${ }^{107}$ In the second program, students bused from another segregated school-Washington Irving-to other, predominantly white schools were compared with non-bused students at Croton. As in the previous case, white children at the receiving school continued to improve at their customary rate in reading. The children from Washington Irving School, however, gained significantly more than the non-bused children at Croton. The thirty bused pupils achieved a mean growth in months double that of the non-bused children. ${ }^{108}$

\section{III}

\section{Studies Showing No Positive Effect of Interracial Schooling on Academic Achievement}

This section is concerned with those studies which fail to show a positive impact of desegregation on academic achievement. In some cases, the lack of positive impact is due to the fact that the researcher failed to control either for intelligence or socioeconomic status and failed to obtain achievement scores for Negro and white students for the period prior to desegregation. Thus it is not possible to ascertain whether the rate of achievement increased or declined as a result of desegregation. Where desegregation studies have failed to take these factors into account, the results are almost meaningless. The academic achievement of approximately 600 Negro and white high school students in Angleton, Texas-after a year of desegregation-was analyzed by James Bryant. ${ }^{109}$ Desegregation was found to have no effect on academic achievement, but the study suffered from all of the defects just noted.

The six-year desegregation experience of Riverside, California has been extensively analyzed by Harold Gerard and his colleagues. ${ }^{110}$ While finding that desegregation led to improvements in the capacity of children to gain

107. Hearing Before the U.S. Comm'n on Civil Rights (Rochester, N.Y.), at 323-26 (1967).

108. Id.

109. See J. Bryant, Some Effects of Racial Integration of High School Students on Standardized Achievement Test Scores, Teacher Grades, and Drop-out Rates in Angleton, Texas, 1968 (unpublished doctoral dissertation at University of Houston).

110. The following discussion is based on a series of drafts of separate articles, kindly supplied to the author by Professor Harold B. Gerard. These are to be published as a group in a forthcoming issue of Journal of Social Issues, under the editorship of Professor Gerard. Since the published versions of the articles may well differ from the drafts, quotations from these articles have been kept to a minimum. 
self-direction, little evidence was found that desegregation resulted in achievement gains in the desegregated schools. ${ }^{111}$ As part of this overall investigation of Riverside's desegregation experience, children's speech characteristics were studied. Minority children appeared to exhibit no "language deficit" upon entering school, nor was there any evidence that language development differed between minority and majority groups, although minority children who went through the desegregation experience tended to talk less freely. ${ }^{112}$

Desegregation in the Riverside schools did not stop the growing trend towards a greater disparity in achievement between Anglo and minority children found in most comparisons of the academic progress of minorities with that of whites. Gerard suggested that "the inevitable invidious comparison undoubtedly had deleterious effects on the minority children." ${ }^{113}$ He also noted that the relative deterioration occurred in the context of schools which had 80 per cent or more white student enrollment. It was found that minority students still operated somewhat as outsiders in the classrooms, even after a period of over four years. Since the Gerard group felt that "the social climate of the classroom is the most important determinant of the child's success," noninvolvement in "the work structure of the classroom" led to low achievement by minority children. ${ }^{114}$ Acceptance by white children was more likely to lead to higher achievement by minority children, especially the more able ones. ${ }^{15}$ The Riverside study clearly revealed the power that peer acceptance and teacher attitudes have on the achievement of minority children. Teachers who deprecated the ability of minority children to learn usually saw the children fall behind their Anglo classmates. At the same time, some teachers who were not overtly discriminatory nevertheless were "patronizing." In other words, they at first tended to be "easier" in grading minority children; ${ }^{16}$ this did not lead to higher achievement among these children.

Gerard and his colleagues view the Riverside experience as desegregation without integration. They speculate that more sweeping measures of desegregation might have led to other outcomes. They argue that successful desegregation depends more on the creation of beneficial classroom structures than on personality changes in the students. ${ }^{117}$

Mabel Purl, Director of Research for the Riverside schools, has been more concerned with discovering access points for future change than in evaluating the desegregation experience in that school district. She has compiled achievement test results for 529 minority students enrolled in nineteen schools in the

\footnotetext{
111. Id.

112. Id

113. Id.

114. Id.

115. Id .

116. Id.

117. Id
} 
first, second, and third grades during 1972-73.18 During that period, these minority students achieved at or above national norms on the various Cooperative Primary Tests which assess achievement in Listening, Word Analysis, Mathematics, and Reading. There was little difference between MexicanAmerican and Negro children in test results.

How, in the face of the overall failure of desegregation to generate improvement in achievement, did more than a third of the minority students in the first three grades in Riverside make such achievement gains? The conventional reply to this type of query is to suggest that the high achievers are students who came from families of relatively high socioeconomic status. However, Purl studied the relationship of socioeconomic status to achievement of high-scoring minority students, and while she found the relationship to be significant, there were considerable variations in scores that had little or nothing to do with socioeconomic status. ${ }^{119}$ Purl examined the two minorities (Negro and Mexican-American) in four schools and found a negative relationship between socioeconomic status and achievement in several cases. She suggests that her finding "has made competing explanations such as school or teacher level causes more worthy of exploration." 120 This conclusion is consonant with the views of the Gerard group. ${ }^{121}$

The most widely publicized study is that of David Armor who concludes from his analysis of studies of five cities which, by and large, covered a one year period of desegregation: "[n]one of the studies were able to demonstrate conclusively that integration has had an effect on academic achievement as measured by standardized tests." ${ }^{122}$ A study of longer-term effects of desegregation upon which he bases many of his conclusions is that of the Riverside, California school system for which there were data over a five year period. However, Purl states that Armor actually added together two studies of the same two and one-half year period and overlooked other significant factors as well. ${ }^{123}$

In a study of students attending kindergarten through grade two in segregated and non-segregated schools in a northern surburban community, desegregation appeared to have no effect on academic achievement. ${ }^{124}$ In several

118. This compilation was supplied to the author by Mabel Purl, Director of Research, Riverside Unified School District, Riverside, Cal.

119. See M. Purl, The Relationship of SES to Higher Achieving Minority Pupils, July 1974 (unpublished document on file with Riverside Unified School District, Riverside, Cal.).

120. Id. at 1

121. See note l10 supra.

122. Armor, The Evidence on Busing, 28 Pub. Interest 90, 99 (Summer 1972). In view of the wide dissemination of the article, there is no need here to describe the studies analyzed by Armor.

123. Orfield, School Integration and Its Academic Critics, 5 Civil Rights Dig. 2, 8 (Summer 1973). The criticism which has received most attention is that in Pettigrew, Useem, Normand, \& Smith, Busing: A Review of "The Evidence," 30 PuB. InTEREST 88 (Winter 1973). Orfield, supra, notes that Armor himself has qualified his conclusions about one of the five cities he studied in testimony before a Senate committee, in light of new findings of achievement gains of minority students in the integrated situation compared to the control group.

124. See D. Long, Educational Performance in Integrated and Segregated Elementary Schools 1968 (unpublished doctoral dissertation at Yeshiva University). 
respects, however, the population studied by Long was quite different from most others reported in this article. The Negro children were not economically disadvantaged, they scored at least at the level of the national norm for the achievement tests in both the segregated and non-segregated schools, and they "had comparable staffs, facilities, and educational programs."125 Vane's study in another suburban school district-comparing two groups of seventeen Negro children, matched by IQ score and parent's occupation, over their entire school career-indicated that racial composition had no impact on achievement. ${ }^{126}$

Similarly, a study of Negro children in two Ypsilanti, Michigan schools, one all-Negro and the other a school with 45 per cent Negro students, indicated that there was no statistically significant difference between the two groups in achievement gains. ${ }^{127}$ This can not be explained by differences between the two groups of students in socioeconomic background or in IQ scores since they were substantially the same.

Robert Klein, at the University of South Carolina, studied the initial effects of desegregation during an eight month period in three high schools located in a southern metropolis: ${ }^{128}$ one recently desegregated, one all-Negro, and the other virtually all-white. Higher scores on mathematics and biology were first registered for Negro children in the desegregated school, but when parental occupation, family size, and parental education were controlled, this superiority disappeared. Klein concluded that " $[t]$ he integrated school setting is neither educationally deleterious nor educationally beneficial for Negro students, at least over an eight-month period." ${ }^{29}$ He also observed that "[t]he academic achievement of matched groups of integrated white and Negro students did not differ significantly. . . The academic achievement of matched groups of segregated Negro students and integrated white students did not differ significantly." 130

Otis Geiger has also reported on a study in a southern city, undertaken after one year of desegregation. Instead of tracing the progress of individual children, he focused on the effect of racial composition of classes on achievement. He reported that "no significant relations were found between percentage of Negroes in the class and amount of achievement." 131 The results of the

125. Id. at 80,85 .

126. Vane, Relation of Early School Achievement to High School Achievement When Race, Intelligence and Socioeconomic Factors Are Equated, 3 Psychology iN The Schools 124, 128 (1966).

127. See N. Radin. A Comparison of the Test Performance of Negro Students Attending All-Negro and Integrated Elementary Schools in One Community, April 15, 1966 (unpublished paper on file with the Ypsilanti Public School District, Ypsilanti, Mich.).

128. Se R. Klein, A Comparative Study of the Academic Achievement of Negro 10th Grade High School Students Attending Segregated and Recently Integrated Schools in a Metropolitan Area of the South, 1967 (unpublished doctoral dissertation at the University of South Carolina).

129. Id. at 49 .

130. Id.

131. See O. Geiger, Effects of Desegregation on Classroom Achievement 27, 1968 (unpublished doctoral dissertation at the Lniversity of South Carolina). 
study, Geiger observed, "suggest that fears of necessary detrimental effects of desegregation on classroom achievement may not be firmly based." 132 Of course, the results also show that beliefs that desegregation would foster higher achievement are unsupported..$^{133}$

Two studies undertaken in Ann Arbor failed to find a positive gain in reading achievement after one to three years of desegregation. One study, by Frank Aberdeen, found that a single grade experienced an increase in reading achievement along with greater social acceptance from white classmates. Aberdeen concedes, however, that no general conclusion about desegregation and achievement can be derived from his study. ${ }^{134}$ His failure to use control groups makes his study even more inconclusive. In a similar study, a control group was used, but the results were the same. ${ }^{135}$

Moorfield found that desegregation had no effect on the achievement scores of minority students in Kansas City, Missouri. ${ }^{136}$ Whether or not desegregation has actually occurred is questionable, however. Students from six predominantly Negro schools were bused to twelve receiving schools. One of the receiving schools had a Negro enrollment of 65.8 per cent before busing and 99.3 per cent after busing, while another had 35.8 per cent before and 42.8 per cent after. ${ }^{137}$ Out of the total number of minority students bused, one-fifth were bused to these two schools. ${ }^{138}$ Achievement data are not reported by individual school.

Elliott and Badal attempted to determine whether the "racial composition of the school make[s] a difference in achievement when scholastic aptitude is controlled." ${ }^{139}$ Their subjects were 4,693 fifth-graders. Schools were classified by per cent Negro: 80 per cent and over, 46 to 79 per cent, 11 to 40 per cent, and 10 per cent and less. Every child took an aptitude test (SCAT) and three

132. Id. at 29 .

133. Several other studies have also found no effect on achievement scores after desegregation has occurred. See, e.g., H. Walberg, An Evaluation of an Urban-Suburban School Bussing Program: Student Achievement and Perception of Class Learning Environments 9-10, (1971); E. Clark, Analysis of the Differences Between Pre and Post Test Scores (Change Scores) on Measures of Self-Concept, Academic Aptitude, and Reading Achievement Earned by Sixth Grade Students Attending Segregated and Desegregated Schools, 1971 (unpublished doctoral dissertation at Duke University); R. Marcum, An Exploration of the First-Year Effects of Racial Integration of the Elementary Schools on a Unit School District, 1968 (unpublished doctoral dissertation at the University of Illinois).

134. See F. Aberdeen, Adjustment to Desegregation: A Description of Some Differences Among Negro Elementary School Pupils, 1969 (unpublished doctoral dissertation at the University of Michigan).

135. See P. Carrigan \& F. Aberdeen, Some Early Effects of Compulsory Desegregation on Elementary School Children (1970).

136. See T. Moorfield, The Busing of Minority Group Children in a Big City School System, 1967 (unpublished doctoral dissertation at the University of Chicago).

137. Id. at 25 , Table 2.

138. Id. at 22 , Table 1 .

139. Elliott \& Badal, Achievement and Racial Composition of Schools, 16 CAL. J. Ed. ResearCh 160 (1965). 
achievement tests (STEP). Mathematics achievement scores rose as the per cent Negro enrolled fell. Writing achievement scores also rose for the two (out of six) highest ability levels of children; for the lower ability levels, no significant differences were found. Reading achievement scores seemed altogether unaffected by the racial composition of the school. All in all, concluded Elliott and Badal, racial composition makes no important difference for achievement when scholastic aptitude is controlled.

A study of Richmond, California, undertaken by Alan Wilson, concludes that the "racial composition of the school, while tending to favor Negro students in racially integrated schools, does not have a substantial effect-not nearly so strong as the social-class composition of the school."140 Wilson also found that the social class composition of the school had more effect on Negro than on white students, although he notes that "[ $t]$ here are hardly any Negroes in our sample in predominantly white schools or predominantly upper [social] status schools,"141 meaning that the Negro sample in the Richmond study was too small to be able to test the relation of social class and race in schools of varying racial composition. It should also be noted that Wilson used the school rather than the classroom as the unit of analysis. Thus if the school system being studied resorts to tracking and ability grouping practices, there may be internal segregation even though the school is said to be desegregated. ${ }^{142}$

Finally, Denmark and Guttentag investigated the effects of non-segregated pre-schooling on the cognitive skills of sixty-three four-year-old Negro children. ${ }^{143}$ Four pre-school groups were organized, only one of which was integrated. The researchers concluded that a good, creative, enjoyable learning climate may be more important than the racial composition of the experience. ${ }^{144}$

\section{IV \\ Studies Showing a Negative Effect of INTERRacial Schooling on ACADEmic Achievement}

As noted at the outset, there is little reason to believe that desegregation has negative consequences for nonwhites. To be sure, desegregation-or any other

140. 2 U.S. Commission on Civil Rights, Racial Isolation in the Public Schools 186 (1967).

141. Id. at 184 .

142. It has been pointed out that school systems which maintain classrooms of heterogeneous ability

tend to record the most encouraging improvements in academic achievement after desegregation. By contrast, systems ... . which increase [the] use of ability grouping after desegregation, have tended to show the most disappointing results.

Pettigrew, $A$ Sociological View of the Post-Bradley Era, 21 Wayne L. Rev. 813, 821 (1975).

143. See Denmark \& Guttentag, Effect of Integrated and Non-Integrated Programs on Cognitive Change in Pre-School Children, 29 Perceptual \& Motor Skills 375 (1969).

144. Id. at 379. 
significant event-will disturb the progress of some children in any large sample. But in this article, the focus has been on the net effects and only two studies of the dozens reviewed herein report that more students than not actually experienced lower rates of achievement as a result of attending a racially mixed rather than a segregated school.

A study of 224 Negro students-drawn from ten predominantly black schools and bused to thirty-two predominantly white schools in Seattle-found that while their attendance records in their new schools improved sharply, their school record as measured by grades suffered: " 43 per cent of the total group are doing poorer than they did last year, 41 per cent are doing the same, and 6 per cent are doing better." 145 Because no achievement test scores are reported, however, it is not possible to know whether the absolute achievement of bused children rose or fell-achievement scores and grades are not always highly correlated in desegregated schools.

A Florida study examined changes in achievement between the academic years of 1969-70 and 1970-71 for Dade County elementary school students. Black students in grades two, four, and six, who had remained in a predominantly black school, attained higher levels of achievement than did those who moved to desegregated schools, as did black junior high school students who remained in black schools. ${ }^{146}$

$\mathrm{V}$

\section{Studies Showing the EfFect of Busing on Academic Achievement}

Because of the emphasis given to busing by both those who see it as the most feasible way to achieve school desegregation and those who view busing as the symbol of attempts to destroy the neighborhood schools concept, ${ }^{147}$ it is surprising that the possible educational consequences of busing have received the attention of only a handful of researchers.

By far the most sophisticated and comprehensive study of the effects of busing, involving 450 schools, is that conducted by James A. Davis as part of the Southern Schools research of Robert Crain and his associates. ${ }^{148}$ The study, which examines the effects of busing on tension in schools, student morale,

145. See A. Hammond, L. Sawhill, \& R. Williams, A Survey of the Adjustment of the Negro Students Who Transferred to Schools Outside Their Neighborhoods During 1963-1964 Under the New Seattle School Board Rulings 48, 1964 (unpublished master's thesis at the University of Washington).

146. Id. at 25,55 .

147. Mandatory busing for segregation was a standard practice throughout the South until well into the 1960's. In the early 1970's more students in the South were transported to public school by a motor-powered vehicle (57.5 per cent) than by walking and/or bicycle-riding (42.5 per cent). U.S. Department of Transportation, School Bus Task Force, Pupil. Transportation Safety Program Plan (1973).

148. See 2 Southirn Schools. 
race relations, and academic achievement, gave particular attention to the need to control for the social background of students. The study concludes: ${ }^{14 !}$

First, there is no evidence that busing per se has any negative consequences. On the contrary. the strongest finding in the set is the association between busing white students and benign levels of tension in the schools.

Second, there is no evidence that attending ome's oum neighborhood school has any effects, positive or negative, on a school's achievement levels or social climate $^{1.50}$

In a study of five West Virginia high schools, Straley compared 348 transported with 256 non-transported seniors-without considering the race of the students. Achievement test scores were significantly higher for the nontransported students; the difference was greater for boys than for girls. Academic grades, however, were the same for both transported and nontransported groups. When Straley matched students in both groups by IQ and sex, the differences between female students who were transported and those who were not disappeared, while for male students, the differences narrowed but remained statistically significant. Straley could find no relationship between academic achievement and distance transported, ${ }^{151}$ so the differences remain unexplained.

Among the remaining busing studies are the following: Davies, in a study of a school in Volusia County, Florida, analyzed the achievement record of fiftyfive pairs of transported and non-transported elementary school students. ${ }^{1 \overline{2}}$ Non-transported students attained a higher rate of achievement in mathematics but not in other subjects. Another study investigated 240 fourth, fifth, and sixth-graders in an urban area of Oklahoma, half of whom were transported and 98 per cent of whom were Caucasians. In no area of achievement measured by the lowa tests was there a significant difference between transported and non-transported students. ${ }^{153}$ A third study found statistically significant achievement differences in favor of a non-transported group of second-grade students. No difference, however, was found for fourth and sixth grade stu-

149. Ir. at 118

150. This should not be taken to mean that the characteristics of the school one attends do not affect achievement. Busing more children from certain types of schools to others may affect achievement. but not because of the bus ride itself or the fact that the school is or is not the closest to the students home.

151. See H. Straley. A Comparative Study of the Academic Achievement and Social Adjustment of Transported and Non-Transported High School Seniors, 1956 (unpublished doctoral dissertation at the University of Virginia).

152. See E. Davies. A Comparative Study of the Academic Achievement of Transported and Non-Transported Pupils at Holly Hill Elementary School, Holly Hill, Florida, 1969 (unpublished master's thesis at Stetson University).

153. See D. White, The Effects of Public School Transportation upon the Overall School Adjustment of Urban Elementary School Students, 1970 (unpublished doctoral dissertation at the University of Oklahoma). Str also White, Effects of Bussing on Urban School Students, 29 ED. LEADERSHIP 255, 256-57 (1971). 
dents in the same study. ${ }^{154}$ The fourth study, which compared students who were bused with those who walked to desegregated schools in Evanston, IIlinois, found that those bused were more likely to experience larger achievement gains. ${ }^{135}$

In sum, while the existing research is quite limited, attribution of negative educational effects to mandatory student transportation for purposes of desegregation is unwarranted by research evidence thus far available. Those studies which show some negative effects of busing are countered by studies that show no losses in academic performance due to busing. Moreover, even when some negative effects are found, they seem to defy theoretical explanation. This is in part due to the failure adequately to control for the social background of students. It seems likely that bused students come from more rural areas. In the South, this may mean that bused students are poorer while in other areas distance from school may be positively related to family wealth. While it is necessary that more research be done on this inflammatory issue, there seems to be little or no reason to believe that busing children to a newly-desegregated school would have a different impact on students academic performance than creating a desegregated school by re-drawing attendance boundaries or by pairing of schools.

\section{Conclusion}

A review of these studies leads me to conclude that, overall, desegregation does indeed have a positive effect on minority achievement levels. Why and under what circumstances this is so is not yet clear, as the studies differ in too many ways to permit us to draw more specific conclusions: the measures of achievement are not the same from study to study; the extent to which schools are truly integrated is seldom well defined by researchers; and many of the studies do not adequately control for factors other than desegregation-such as socioeconomic status-that might influence academic achievement. And the fact that the processes by which desegregation occurs vary substantially between school districts and between schools also makes comparison difficult. For example, many of these studies involve voluntary desegregation. Obviously, the students of parents who have chosen to bus their children to predominanty white schools may be importantly different from those not bused even though $I Q$, social class background, and other student characteristics are similar.

All of these qualifications of the findings of available research does not mean the research provides no guidance. As noted at the outset, there seems to be agreement that (1) the achievement levels of white majorities in desegre-

154. Dunlop. Harper. \& Hunka. The Influene of Transperting Children to Centralized Schools upon Achievement and Attendance. 44 Ed. Administration \& Supervision 191, 196 (1958).

155. J. Hsia, supra note 88. 
gated schools do not decline; (2) the net effect of desegregation on the academic achievement levels of nonwhites, in most studies, is positive and in others is at least neutral (since most of the research has been with blacks, further research will be necessary to determine whether this is true of achievement levels of other minorities as well); and (3) the instrument for obtaining integration-whether through busing, pairing of schools, altering of attendance zones, etc.- has no direct bearing on the achievement of the children involved.

In addition, there appears to be substantial agreement among desegregation researchers that the likelihood that desegregation will lead to gains in achievement of racial minorities is greatest when the following characterize the desegregated schools:

1. a relative absence of interracial hostility among students,

2. teachers and administrators who understand and accept minority students, encouraged and reinforced by aggressive in-service training programs,

3. the majority of students in a given classroom are from middle and/or upper socioeconomic classes,

4. desegregation at the classroom as well as at the school level, particularly in elementary schools,

5. no rigid ability grouping or tracking, particularly in elementary schools,

6. an absence of racial conflict in the community over desegregation, and

7. younger children are involved (though this last conclusion should be considered very tentative).

Some of the apparent positive impact of racial integration on academic achievement that is found in some of the studies is traceable to interclass rather than interracial mixing of students. Of course, since nonwhite children are disproportionately from working class and poor families, racial integration also tends to result in socioeconomic mixing.

Since researchers can study only that which social practice puts before them, many of the effects of desegregation reported in this article are investigations of what is essentially token desegregation rather than of integration; until very recently, this was the only kind available. Tokenism, by its nature, sets all the psychological burdens of desegregation upon the shoulders of the minority child. It also accentuates his or her own awareness of minority status, and may encourage among white students and teachers a certain paternalism toward the minority child which ill-serves both sides of the transaction. Tokenism is thus an unfavorable framework for productive desegregation. Moreover, many of the studies cover only a single year of desegregation. The scale of desegregation in the South has increased considerably since 1969, but little research has been undertaken in the South until the Crain study of 555 southern schools in districts receiving federal funds under the Emergency 
School Assistance Program. ${ }^{156}$ This data base will be a fruitful source for further research and analysis in the future.

The present generation of Americans has seen the passing of the traditional one-race school. Recent progress in desegregation has brought children together to an unprecedented degree. Under segregation, minority children were not permitted equal opportunities in any meaningful sense. A black-white achievement gap seemed to be a permanent fixture of schools. It appears, however, that more of ten than not, academic achievement of minority children improves when they learn together as part of a deliberate desegregation process or as a result of non-segregated housing.

156. See 1-2 SOLTHERN SCHOOLS. 